\title{
Physicochemical Properties and Surface Charge Characteristics of Arid Soils in Southeastern Iran
}

\author{
A. H. Moghimi, ${ }^{1}$ J. Hamdan, ${ }^{1}$ J. Shamshuddin, ${ }^{1}$ A. W. Samsuri, ${ }^{1}$ and A. Abtahi ${ }^{2}$ \\ ${ }^{1}$ Department of Land Management, Faculty of Agriculture, Universiti Putra Malaysia, 43400 Serdang, Selangor, Malaysia \\ ${ }^{2}$ Department of Soil Science, Faculty of Agriculture, Shiraz University, Shiraz 7915847669, Iran
}

Correspondence should be addressed to A. H. Moghimi; moghimiabolhasan@gmail.com

Received 2 March 2013; Revised 15 May 2013; Accepted 20 May 2013

Academic Editor: Davey Jones

Copyright (C) 2013 A. H. Moghimi et al. This is an open access article distributed under the Creative Commons Attribution License, which permits unrestricted use, distribution, and reproduction in any medium, provided the original work is properly cited.

\begin{abstract}
The majority of previous studies on surface charge characteristics were done on tropical and subtropical soils. Information of such studies in the arid regions is limited. A study was conducted to investigate the relation between soil chemical and mineralogical properties and surface charge characteristics of an arid region in Southeastern Iran. Eight soil pedons, representing the alluvial and the colluvial deposits, were described, and their mineralogical and physicochemical properties were examined. The common clay minerals in the studied area are smectite, palygorskite, kaolinite, chlorite, and illite. The point of zero charge $\left(\mathrm{pH}_{0}\right)$ values are low (2.85-3.35) in all soils mostly affected by organic carbon (OC) and free iron oxide $\left(\mathrm{Fe}_{\mathrm{d}}\right) \cdot \mathrm{pH}_{0}$ has a significant negative correlation with $\mathrm{pH}$ under field conditions $\left(r=-0.45^{*}, P<0.05\right)$. The point of zero net charge (PZNC) levels for all the soils were $<2$, due to the excess negative charge in these soils. The estimated PZNC values were less than $\mathrm{pH}_{0}$ in all soils because of the high permanent negative charge in these soils. The permanent negative charge $\left(\sigma_{p}\right)$ of the soils studied is high and it has a significant positive correlation with $\mathrm{pH}, \mathrm{CEC}, \mathrm{Na}, \mathrm{Mg}$, $\mathrm{SAR}$, clay content, palygorskite, OC, and $\mathrm{Fe}_{\mathrm{d}}$.
\end{abstract}

\section{Introduction}

Soil surface charges affect the chemical properties of soil by varying the quantity of electric and surface charge density. Surface charge properties have an important bearing on the migration of ions in soil, the formation of organomineral complexes, soil structure, plant nutrition, and the dispersion, flocculation, swelling, and shrinkage of the soil fractions [1]. Based on differences in the surface properties, soils can be classified into two basic categories: permanent-charge soils and variable-charge soils $[2,3]$.

Point of zero charge (PZC) often denoted as $\mathrm{pH}_{0}$ is one of the most important parameters used to describe variablecharge surfaces [4]. Uehara and Gillman [5] indicated that $\mathrm{pH}_{0}$ is the $\mathrm{pH}$ where the amounts of negative and positive charge of variable charge components where these are equal. The $\mathrm{pH}_{0}$ value for the temperate region of Iran was reported in the range of about 2.6 to 3.75 [6]. Anda et al. [7] reported that the $\mathrm{pH}_{0}$ of three Oxisols in Malaysia was about 3.9 to 5.7. The previous studies showed that the $\mathrm{pH}_{0}$ values decrease with increasing organic matter content and increase with increase in sesquioxides [6-8]. Taubaso et al. [9] reported that the $\mathrm{pH}_{0}$ values of Argentinean provinces soils were smaller than the $\mathrm{pH}$ in water, indicating that these soils had negative charge under natural conditions.

Gonzales-Batista et al. [10] reported that for systems free of permanent charge, the point of zero net charge (PZNC) should coincide with $\mathrm{pH}_{0}$, but for systems where permanent and variable charges coexist, $\mathrm{PZNC}$ may differ from $\mathrm{pH}_{0}$. Usually in the young soils (Entisols or Inceptisols) PZNC is lower than its $\mathrm{pH}_{0}$ and higher than $\mathrm{pH}_{0}$ if the soils are highly weathered, such as Oxisols [9]. In addition, the model of Uehara and Gillman [11] and Yu [2] predicts that in soils having permanent negative charge, the PZNC value is lower than the $\mathrm{pH}_{0}$ and vice versa.

Most studies on soil surface charge properties were conducted in tropical and subtropical regions where the soils are poor and low in negative charge. In Iran, Sharami et al. [6] conducted similar study for temperate soils of the Northern region but no study was done on arid regions of Southern Iran or elsewhere in the world. The electrochemical properties of soils are useful fundamental knowledge in solving the fertility 
problems of soils of the arid regions. For example, in the arid regions, the $\mathrm{NH}_{4}^{+}$fixed by soil particles and leached out as $\mathrm{NO}_{3}{ }^{-}$form due to high permanent negative charge in the surface of soil particles [12] in comparison with highly weathered soils where $\mathrm{NO}_{3}{ }^{-}$leaching because of high positive charge present in the soils [13]. The objectives of this study were to determine the physicochemical and mineralogical properties, the $\mathrm{pH}_{0}, \mathrm{PZNC}$, and permanent negative charge $\left(\sigma_{p}\right)$ and to determine the relation between $\mathrm{pH}_{0}$ and $\sigma_{p}$ with characteristics of arid soils in Southeastern Iran.

\section{Materials and Methods}

2.1. Description of the Study Area. The studied area is located in the province of Hormozgan, Southeastern Iran, between latitude $28^{\circ} 8^{\prime}$ and $28^{\circ} 15^{\prime}$ North and longitudes $56^{\circ} 5^{\prime}$ and $56^{\circ}$ $15^{\prime}$ East (Figure 1). The climate is arid with an average annual precipitation of about $162 \mathrm{~mm}$ and evaporation of $4243 \mathrm{~mm}$. Burdon [14] reported that the estimated potential evapotranspiration could be in excess of 50 times the mean annual precipitation. The temperature regime is hyperthermic with an aridic and ustic moisture regimes [15]. The sedimentary rocks accompanying marine deposits of the Tertiary age formed the catchment area, which is predominantly composed of thick alluvial and colluvial materials occasionally deposited by the Dehshaykh River for the past thousands of years. The river is dry most of the time except during heavy downfall. The catchment is currently cultivated with wheat, maize, potato, and watermelon as important agricultural crops [16].

Eight pedons were selected among the dug profiles representing alluvial fan and colluvial deposits along the slope area of the catchment by geopedology approach and different soil horizons were sampled for laboratory analysis. The morphological properties of the soils were described in the field [17] and were classified according to the USDA Soil Taxonomy [18].

\subsection{Methods}

2.2.1. Physical and Chemical Analyses. Field study and samples collection were carried out in the summer season of 2009 (August to September). The soil samples were air-dried and sieved with a $2 \mathrm{~mm}$ sieve and kept in plastic bags prior to analysis.

The particle size analysis was carried out by the pipette method [19]. Organic matter content of the soil was determined by the wet combustion procedure of Walkley and Black [20] and $\mathrm{Fe}_{2} \mathrm{O}_{3}$ was estimated by the dithionite-citratebicarbonate method [21]. The $\mathrm{pH}$ was measured in the supernatant suspension of $1: 1$ soil : water suspension $\mathrm{pH}$ [17], 1:2.5 liquid $0.01 \mathrm{M} \mathrm{CaCl}_{2}$ solution $\left(\mathrm{pH}_{\mathrm{CaCl}_{2}}\right)$ [22] and $1: 2.5$ soil : $\mathrm{H}_{2} \mathrm{O}\left(\mathrm{pH}_{\mathrm{H}_{2} \mathrm{O}}\right)$, and $1: 2.5$ soil : $1 \mathrm{M} \mathrm{KCl}$ solution $\left(\mathrm{pH}_{\mathrm{KCl}}\right)$ [23]. The bulk density $\left(\rho_{b}\right)$ was estimated by core method [24], and the electrical conductivity (EC) analysis was measured in the saturated extract [25]. The calcium carbonate equivalent (lime) was measured by acid neutralization [26]; exchangeable cations content and the cation exchange capacity (CEC) of the soils were determined by the $1 \mathrm{M}$ ammonium acetate

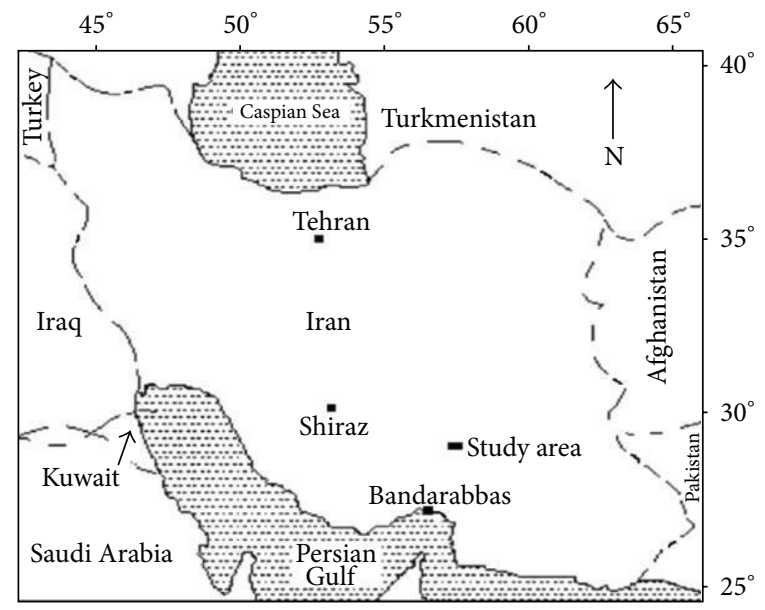

FIGURE 1: Location of the study area.

( $\mathrm{pH}$ 7) method. The exchangeable cations $\left(\mathrm{Ca}^{2+}\right.$ and $\mathrm{Mg}^{2+}$ ) in the leachate were determined by atomic absorption spectrophotometer (AAS, Perkin-Elmer, 047-1705), whereas $\mathrm{K}^{+}$ and $\mathrm{Na}^{+}$were measured by flame spectrophotometer. The soil solution data $\left(\mathrm{Na}^{+}, \mathrm{Ca}^{2+}, \mathrm{Mg}^{2+}\right.$ given in $\left.\mathrm{cmol}_{\mathrm{c}} \mathrm{kg}^{-1}\right)$ was used to calculate the sodium adsorption ratio $(\mathrm{SAR})$, where $\mathrm{SAR}=$ $\mathrm{Na}^{+}\left[\left(\mathrm{Ca}^{2+}+\mathrm{Mg}^{2+}\right) / 2\right]^{-0.5}$.

2.2.2. Determination of Point of Zero Charge. Point of zero charge (PZC), denoted as $\mathrm{pH}_{0}$, is defined as the $\mathrm{pH}$ at which the net charge on the variable charge components is zero and was determined according to the method of Gillman and Sumner [27]. Six portions of $2 \mathrm{~g}$ of $2 \mathrm{~mm}$ air-dried samples were weighed into $50 \mathrm{~mL}$ plastic centrifuge tubes and shaken with $20 \mathrm{~mL}$ of $0.1 \mathrm{M} \mathrm{CaCl}_{2}$ for $2 \mathrm{~h}$ to saturate the soil with $\mathrm{Ca}$. The suspension was centrifuged (3000 rpm, $10 \mathrm{~min})$ and the supernatant was discarded. The $\mathrm{Ca}$ saturated soil was washed twice with $20 \mathrm{~mL}$ of $0.002 \mathrm{M} \mathrm{CaCl}_{2}$ and after the third addition of $20 \mathrm{~mL}$ of $0.002 \mathrm{CaCl}_{2}$, the $\mathrm{pH}$ was adjusted to six values of $0.1 \mathrm{M} \mathrm{HCl}$ in the range of 3.5 to $6 \mathrm{~mL}$ by dropwise addition. Equilibration of the $\mathrm{pH}$ took several days. When equilibrium occurred for $0.002 \mathrm{M} \mathrm{CaCl}_{2}$, the $\mathrm{pH}$ was recorded as $\mathrm{pH}_{0.002}$, then $0.5 \mathrm{~mL}$ of $2 \mathrm{M} \mathrm{CaCl}_{2}$ was added to each sample and shaken for $3 \mathrm{~h}$, and $\mathrm{pH}$ was recorded thereafter and designated as $\mathrm{pH}_{0.05}$. For each tube, $\delta \mathrm{pH}$ was calculated as $\left(\mathrm{pH}_{0.05}-\mathrm{pH}_{0.002}\right)$. The $\mathrm{pH}_{0}$ was obtained from the plot of $\delta \mathrm{pH}$ against $\mathrm{pH}_{0.002}$. The $\mathrm{pH}_{0}$ was identified as the point where $\delta \mathrm{pH}$ was zero.

2.2.3. Determination of Point of Zero Net Charge. The point of zero net charge (PZNC), the $\mathrm{pH}$ at which net surface charge of the whole system (taking into account both permanent and variable charge colloids) is zero, was obtained by interpolation of the data from the measurement of charge variation with $\mathrm{pH}$. Charge variation with $\mathrm{pH}$ was determined by the fingerprint method of Gillman and Sumner [27]. Two-gram air-dried soil samples in $50 \mathrm{~mL}$ preweighed plastic centrifuge tubes were shaken with $20 \mathrm{~mL}$ of $0.1 \mathrm{M} \mathrm{CaCl}_{2}$ for $2 \mathrm{~h}$ to saturate the soil with $\mathrm{Ca}$. The suspension was 
TABLE 1: General information on the studied pedons.

\begin{tabular}{|c|c|c|c|c|c|c|}
\hline Pedon & Soil classification & Relief & Physiography & Land use & Parent material & Drainage \\
\hline 1 & $\begin{array}{l}\text { Fine loamy, mixed } \\
\text { (calcareous), hyperthermic, } \\
\text { Calcic Haplosalids }\end{array}$ & Flat & $\begin{array}{l}\text { Piedmont alluvial } \\
\text { plain }\end{array}$ & Saline pasture & Calcareous alluvium & Imperfectly drained \\
\hline 2 & $\begin{array}{l}\text { Coarse loamy, mixed } \\
\text { (calcareous), hyperthermic, } \\
\text { Aridic Ustorthents }\end{array}$ & Almost flat & River alluvial plain & Bare & Calcareous alluvium & Well drained \\
\hline 3 & $\begin{array}{l}\text { Fine loamy, mixed } \\
\text { (calcareous), hyperthermic, } \\
\text { Aridic Ustifluvents }\end{array}$ & Almost flat & $\begin{array}{l}\text { Piedmont alluvial } \\
\text { plain }\end{array}$ & Plowed & Calcareous alluvium & $\begin{array}{c}\text { Moderately well } \\
\text { drained }\end{array}$ \\
\hline 4 & $\begin{array}{l}\text { Loamy skeletal, mixed } \\
\text { (calcareous), hyperthermic, } \\
\text { Aridic Ustifluvents }\end{array}$ & Almost flat & $\begin{array}{l}\text { Piedmont alluvial } \\
\text { plain }\end{array}$ & Harvested wheat & Calcareous alluvium & Well drained \\
\hline 5 & $\begin{array}{l}\text { Sandy skeletal, mixed } \\
\text { (calcareous), hyperthermic, } \\
\text { Aridic Ustifluvents }\end{array}$ & Almost steep & $\begin{array}{l}\text { Alluvial-colluvial } \\
\text { fan }\end{array}$ & pasture & Calcareous alluvium & Well drained \\
\hline 6 & $\begin{array}{l}\text { Coarse loamy, mixed } \\
\text { (calcareous), hyperthermic, } \\
\text { Aridic Ustorthents }\end{array}$ & Flat & River alluvial plain & Plowed & Calcareous alluvium & $\begin{array}{l}\text { Moderately well } \\
\text { drained }\end{array}$ \\
\hline 7 & $\begin{array}{l}\text { Fine loamy, mixed } \\
\text { (calcareous), hyperthermic, } \\
\text { Aridic Ustifluvents }\end{array}$ & Almost flat & $\begin{array}{l}\text { Piedmont alluvial } \\
\text { plain }\end{array}$ & Plowed & Calcareous alluvium & Well drained \\
\hline 8 & $\begin{array}{l}\text { Sandy skeletal, mixed } \\
\text { (calcareous), hyperthermic, } \\
\text { Aridic Ustorthents }\end{array}$ & Almost steep & $\begin{array}{l}\text { Alluvial-colluvial } \\
\text { fan }\end{array}$ & Pasture & Calcareous alluvium & Well drained \\
\hline
\end{tabular}

centrifuged (3000 rpm, $10 \mathrm{~min}$ ) and the supernatant was discarded. The Ca saturated soil was washed twice with $20 \mathrm{~mL}$ of $0.002 \mathrm{M} \mathrm{CaCl}_{2}$ and after the third addition of $20 \mathrm{~mL}$ of $0.002 \mathrm{M} \mathrm{CaCl}_{2}$ soil suspension was recorded, and thereafter the $\mathrm{pH}$ was adjusted to different values by dropwise addition of $0.1 \mathrm{M} \mathrm{HCl}$ or saturated $\mathrm{Ca}(\mathrm{OH})_{2}$. The equilibration of the $\mathrm{pH}$ took several days. After the $\mathrm{pH}$ was stable, the suspension was centrifuged and the supernatant was collected to determine $\mathrm{Ca}, \mathrm{Al}$, and $\mathrm{Cl}$ in the entrained solution. The tubes were then weighed to estimate the volume of entrained $0.002 \mathrm{M} \mathrm{CaCl}_{2}$.

The soil was then extracted with $20 \mathrm{~mL}$ of $1 \mathrm{~m} \mathrm{NH}_{4} \mathrm{NO}_{3}$, and $\mathrm{Ca}, \mathrm{Al}$, and $\mathrm{Cl}$ were determined in the extract. Allowing for entrained $\mathrm{Ca}, \mathrm{Al}$, and $\mathrm{Cl}$, the amounts of cation $\mathrm{Ca}^{2+}+$ $\left.\mathrm{Al}^{3+}\right)$ and anion $\left(\mathrm{Cl}^{-}\right)$adsorbed were calculated and equated with total negative $\left(\mathrm{CEC}_{\mathrm{T}}\right)$ and positive (AEC) charge, respectively. The amount of $\mathrm{Ca}$ adsorbed was equated with basic cation exchange capacity $\left(\mathrm{CEC}_{\mathrm{B}}\right)$. Aluminum and $\mathrm{Ca}$ were determined by AAS and $\mathrm{Cl}$ measured by silver nitrate titration method [28]. The PZNC was identified as the $\mathrm{pH}$ value where total negative and positive charges are equal. The permanent charge was estimated as the difference between $\mathrm{AEC}$ and $\mathrm{CEC}_{\mathrm{T}}$ values at $\mathrm{pH}_{0}[29]$.

2.2.4. Mineralogical Analyses. Removal of chemical cementing agents and separation of the different size fractions of soils were carried out according to Mehra and Jackson [21], Kittrick and Hope [30], and Jackson [31]. Organic matter and carbonate were removed with $30 \% \mathrm{H}_{2} \mathrm{O}_{2}$ and $1 \mathrm{~N} \mathrm{HCl}$, respectively. X-ray diffraction (XRD) studies were carried out on both fine and coarse clay fractions, while equal concentrations of clay suspensions were used for all samples in order to allow for a more reliable comparison between relative peak intensities for different samples. Two drops of the prepared suspension were used on each glass slide. The clay samples were finally examined by XRD analysis using a Philips diffractometer with Co $\mathrm{K} \alpha$ radiation in order to allow for a more reliable comparison between the relative heights of peaks in the XRD data. The K-saturated samples were studied both after drying and heating at $500^{\circ} \mathrm{C}$ for $4 \mathrm{~h}$ to identify kaolinite in the presence of trioctahedral chlorite, and samples were also treated with $1 \mathrm{~N} \mathrm{HCl}$ at $80^{\circ} \mathrm{C}$, overnight. Semiquantitative estimation of clay minerals was made by directly converting the diffraction peak areas using the method of Karanthanasis and Hajek [32]. Selected dried clay particles of the soils were studied under a transmission electron microscope (TEM, LEO $912 \mathrm{AB}$ ). The samples dispersed in $100 \%$ alcohol and $100 \mu \mathrm{L}$ of the suspension was dropped on formvar-coated $\mathrm{Cu}$ grids.

The soil chemical and mineralogical properties and their relationship with the surface charge characteristics were analyzed by multiple and simple linear regression using SAS and Excel softwares.

\section{Results and Discussion}

3.1. Field Observation and Soil Classification. The soil chemical data are shown in Table 1. Pedons 1, 3, 7, and 4 are soils developed on the piedmont alluvial plains while pedon 2 
TABLE 2: Some physical properties of the representative profiles.

\begin{tabular}{|c|c|c|c|c|c|c|c|c|}
\hline Soil number & Depth $(\mathrm{cm})$ & Clay & $\begin{array}{l}\text { Silt } \\
(\%)\end{array}$ & Sand & Texture $^{+}$ & Structure* & $\rho_{b}\left(\mathrm{~g} \mathrm{~cm}^{-3}\right)$ & Gravel (\%) \\
\hline \multirow{4}{*}{1} & $0-25$ & 34 & 56 & 10 & $\mathrm{SiCL}$ & WP & 1.54 & - \\
\hline & $25-78$ & 14 & 36 & 50 & L & $\mathrm{Ma}$ & 1.50 & - \\
\hline & $78-110$ & 32 & 48 & 20 & $\mathrm{CL}$ & WG & 1.53 & - \\
\hline & $100-150$ & 12 & 22 & 66 & SL & $\mathrm{Ma}$ & 1.51 & - \\
\hline \multirow{4}{*}{2} & $0-20$ & 10 & 40 & 50 & $\mathrm{~L}$ & WP & 1.52 & - \\
\hline & $20-50$ & 10 & 8 & 82 & LS & $\mathrm{Sg}$ & 1.53 & - \\
\hline & $50-100$ & 12 & 16 & 72 & SL & $\mathrm{Sg}$ & nd & 35 \\
\hline & $100-150$ & 8 & 2 & 90 & $\mathrm{~S}$ & $\mathrm{Sg}$ & 1.36 & - \\
\hline \multirow{3}{*}{3} & $0-30$ & 18 & 38 & 44 & $\mathrm{~L}$ & WG & 1.44 & - \\
\hline & $30-80$ & 16 & 37 & 47 & $\mathrm{~L}$ & WG & 1.40 & - \\
\hline & $80-150$ & 16 & 12 & 72 & SL & $\mathrm{Sg}$ & 1.49 & - \\
\hline \multirow{4}{*}{4} & $0-20$ & 10 & 16 & 74 & SL & $\mathrm{Sg}$ & nd & 30 \\
\hline & $20-70$ & 8 & 16 & 76 & SL & $\mathrm{Sg}$ & nd & 50 \\
\hline & $70-95$ & 14 & 12 & 74 & SL & $\mathrm{Sg}$ & nd & 10 \\
\hline & $95-150$ & 12 & 4 & 84 & LS & $\mathrm{Sg}$ & nd & 50 \\
\hline \multirow{2}{*}{5} & $0-45$ & 18 & 20 & 62 & SL & $\mathrm{Sg}$ & nd & 85 \\
\hline & $45-150$ & 24 & 20 & 56 & $\mathrm{SiL}$ & $\mathrm{Sg}$ & nd & 65 \\
\hline \multirow{3}{*}{6} & $0-42$ & 16 & 34 & 50 & $\mathrm{~L}$ & WG & 1.41 & - \\
\hline & $42-88$ & 10 & 12 & 78 & SL & $\mathrm{Ma}$ & 1.37 & - \\
\hline & $88-150$ & 12 & 26 & 62 & SL & $\mathrm{Ma}$ & 1.41 & - \\
\hline \multirow{3}{*}{7} & $0-36$ & 24 & 42 & 34 & $\mathrm{~L}$ & WG & 1.35 & - \\
\hline & $36-86$ & 30 & 50 & 20 & CL & WG & 1.39 & - \\
\hline & $86-150$ & 26 & 38 & 36 & $\mathrm{~L}$ & WG & 1.41 & - \\
\hline \multirow{3}{*}{8} & $0-30$ & 12 & 14 & 74 & SL & $\mathrm{Sg}$ & nd & 70 \\
\hline & $30-70$ & 10 & 8 & 82 & LS & $\mathrm{Sg}$ & nd & 75 \\
\hline & $70-150$ & 14 & 14 & 72 & SL & $\mathrm{Sg}$ & nd & 80 \\
\hline
\end{tabular}

Texture $^{+}$: SL: sandy loam, LS: loamy sand, L: loam, S: sand, SiL: silty loam, SiCL: silty clay loam. Structure*: Ma: massive, Sg: single grain, WP: weak platy, WG: weak granular, nd: no determine.

and 6 are formed on river alluvial plains. Pedons 5 and 8 are formed on alluvial colluvial fans and sited on a higher slope area. All pedons were dug with a maximum depth of $150 \mathrm{~cm}$ and obvious textural changes throughout the profile were observed. Since the plain is part of an alluvial and colluvial fan, the deposition of materials from the alluvial and colluvial wash varies from time to time creating different textural layers. This was observed in all the soils studied where the soils textural changes were extreme, particularly for the silt and sand content. There were also variations in their structures, which is also associated with the amount of sand and silt in the soils. The soils tend to be massive when the silt content is high, otherwise the structures would be single grain when the sand content is high. The rounded nature of these gravels suggests that they were washed and deposited along part of the plain. All soils were weakly developed and evidenced by weak horizon formation in the profiles. Under the arid environment with annual precipitation value of less than $200 \mathrm{~mm}$ and evaporation of more than $4000 \mathrm{~mm}$, one would surely expect to see slow rate of soil pedological development because of very low rate of $\mathrm{P} / \mathrm{ET}^{0}$ [33].
The eight representative profiles were classified using the USDA Soil Taxonomy [18]. All soils are young and differentiated by their moisture regime. They were identified as Calcic Haplosalids, Aridic Ustorthents, and Aridic Ustifluvents (Table 1).

3.2. Physical Properties. The soil physical data are presented in Table 2. None of the soil physical characteristics show any clear trend with depth. In pedon 1 , the clay content distribution was irregular. In pedons $4,5,7$, and 8 , clay increases with depths, while in pedon 2, it increased only until the top $100 \mathrm{~cm}$. In contrast to the above observations, pedon 6 exhibits a remarkable decrease in clay content with soil depth. In pedons 3 and 4 , the silt content decreases with depth. The sand size particles are dominant in all pedons except for pedons 1 and 7, but their distribution throughout the profile was very irregular. The results are consistent with the nature of alluvial and colluvial deposition that varies from time to time. Khresat and Qudah [34] also observed a similar deposition trend on studying the Azraq Basin in Northeastern Jordan, which is also formed from alluvial and colluvial deposition. 
3.3. Chemical Properties. The soil chemical data of the representative profiles are presented in Table 3. The soils are alkaline and calcareous in nature, containing $19.83 \%$ to $61.45 \%$ $\mathrm{CaCO}_{3}$ throughout the profiles. All soils have $\mathrm{pH}$ values above 7.0 showing that they are alkaline. The average electrical conductivity values exhibited some variations among the soils studied, placing these soils from slightly saline to saline level. In pedons $2,4,5$, and 8 , the soils were noted to be nonsaline with $\mathrm{EC}$ values ranging from 0.4 to $2.64 \mathrm{dS} \mathrm{m}^{-1}$, while soils in pedons 3,6 , and 7 were slightly saline with EC values ranging from 2.1 to $7 \mathrm{dS} \mathrm{m}^{-1}$. Pedon 1 soil was observed to be saline with EC values ranging from 18.11 to $30.5 \mathrm{dS} \mathrm{m}^{-1}$. The $\mathrm{Na}$ content showed slight variability among the soils studied. In pedons 2,5 , and 8 , the amount of $\mathrm{Na}$ was between 0.4 and $6.8 \mathrm{cmol}_{\mathrm{c}} \mathrm{kg}^{-1}$ as compared to pedons $1,3,4,6$, and 7, which $\mathrm{Na}$ ranges between 1.84 in $20 \mathrm{cmol}_{\mathrm{c}} \mathrm{kg}^{-1}$. The soils, however, are nonsodic with SAR values ranging from 0.3 to 7.7. The cation exchange capacity ranges from 1.7 to $41.4 \mathrm{cmol}_{\mathrm{c}} \mathrm{kg}^{-1}$. In pedons $1,3,6$, and 7 , the CEC was between 19.5 and $41.1 \mathrm{cmol}_{\mathrm{c}} \mathrm{kg}^{-1}$ as compared to pedons $2,4,5$, and 8 , with values of 11.7 to 21.5 . The organic carbon content was low in all soils, which is common for soils of these regions where the vegetation is scarce.

The variability of the soil chemical properties again reflects the alluvial and colluvial nature of soil deposition and their rocks origin. According to Navai [35], the predominant rocks surrounding the study area are limestone, dolomite (Jahrom Formation), limestone, marl (Aghajari Formation), limestone, green marl (Mishan Formation), salt domes (Hormoze Formation), and conglomerate (Bakhtiari Formation). The weathered rock materials from these formations were washed to the catchment areas and these contributed to the variability in the soil physicochemical properties.

3.4. Clay Mineralogy. The clay minerals of the examined soils are presented in Table 4 . Based on $d$-spacing the minerals identified through XRD diffractograms are as follows: smectite $(14.02-15,3.18-3.20 \AA)$, palygorskite (10.4$10.6,6.34-6.4,3.23$, and $4.25-4.47 \AA)$, chlorite (7.01-7.11, $3.53 \AA$ ), illite $(9.97-10.09,4.98-5.02 \AA)$, kaolinite (7.2-7.3, $2.28 \AA$ ), and sepiolite (12.10-12.11). The presence of smectite was proven by $\mathrm{Mg}$-saturated clay samples solvated by ethylene glycole, which expanded due to treatment with $\mathrm{Mg}$ saturated.

The common minerals in all samples of the studied area are smectite, palygorskite, illite, chlorite, and kaolinite. Kaolinite is found in all soils with the exception of pedon 8. Sepiolite exists in pedons $3,4,6$, and 7 . The dominance of these minerals in the arid regions agrees with the results obtained by Owliaie et al. [36] and Emadi et al. [37]. Palygorskite and sepiolite are fibrous clays and are considered to be of authigenic origin, inherited from weathered parent materials of the surrounding hills and plateaus [33]. The presence of kaolinite in most soils is probably due to inheritance from the weathering of coarse and fine materials transported from the surrounding upland zones. It may also suggest the occurrence of palygorskite and sepiolite kaolinization that apparently may be due to the effect of organic matter decomposition and fibrous clay destabilization caused by Mg uptake by plants [38].

\subsection{Soil Electrochemical Properties}

3.5.1. Point of Zero Charge Characteristics. The $\mathrm{pH}_{0}$ values varied from 2.8 in subsurface horizon of pedon 2 to 3.35 in the topsoil horizon of pedon 1 (Table 4 ) and were positively correlated with the $\mathrm{Fe}_{\mathrm{d}}$ content $\left(r=0.87^{* *}, P<0.01\right)$ which was far more than its correlation with the OC percentage ( $r=$ $\left.-0.83^{* *}, P<0.01\right)$. The $\mathrm{pH}_{0}$ also has a negative significant correlation with $\mathrm{pH}_{\mathrm{H}_{2} \mathrm{O}}\left(r=-0.45^{*}, P<0.05\right)$. Hence, the $\mathrm{Fe}_{\mathrm{d}}$ content had more effect on $\mathrm{pH}_{0}$ values compared with the $\mathrm{OC}$ content in the soils studied. The respective $\mathrm{pH}_{0}$ values of organic matter and sesquioxides have been reported to decrease and increase, respectively $[8,39]$.

$\mathrm{Li}$ and $\mathrm{Xu}[40]$ reported that the layer silicate clays $(2: 1$ clays) decreased the $\mathrm{pH}_{0}$ values, while the $1: 1$ clay minerals as kaolinite increased the $\mathrm{pH}_{0}$. Besides, Uehara and Gillman [5] reported that the oxides of $\mathrm{Fe}$ and $\mathrm{Al}$ have high $\mathrm{pH}_{0}$ values ( $\mathrm{pH}$ 7-9), while silica $\left(\mathrm{SiO}_{2}\right)$ and organic matter have low $\mathrm{pH}_{0}$ values. Therefore, the low levels of $\mathrm{pH}_{0}$ in the present study were probably related to layer silicate clays (2:1 clays) and high $\mathrm{pH}$ in all the pedons.

The values of $\delta \mathrm{pH}\left(\mathrm{pH}_{0}-\mathrm{pH}_{\mathrm{CaCl}_{2}}\right)$ indicate the evolution of positive and negative charges on the variable charge components [11]. The greatest values of $\delta \mathrm{pH}\left(\mathrm{pH}_{0}-\mathrm{pH}_{\mathrm{CaCl}_{2}}\right)$ were related to subsurface horizon of profile 2 ( -5.10 units), which agreed with its strongly negative net charge in the field conditions (Table 4). The mineralogical data also confirmed the occurrence of significant amounts of layer silicate minerals (smectitic type) in this profile (Table 4). Generally, the variations of $\delta \mathrm{pH}\left(\mathrm{pH}_{0}-\mathrm{pH}_{\mathrm{CaCl}_{2}}\right)$ for all the studied horizons showed a rather high level (between -4.25 and -5.10 units) (Table 4), which was in accordance with their CEC levels (Table 3). However, because of a large quantity of layer silicate minerals (2:1 clays) and a scarcity of $1: 1$ clays and $\mathrm{Fe}_{\mathrm{d}}$, this rising trend from surface to subsurface horizons was not so noticeable.

3.5.2. Point of Zero Net Charge (PZNC). For all the studied soils, the PZNC levels were $<2$, which was probably due to the excess negative charge in these soils. Gonzales-Batista et al. [10] reported that for systems free of permanent charge, PZNC should coincide with $\mathrm{pH}_{0}$, but for systems where permanent and variable charges coexist, PZNC may differ from $\mathrm{pH}_{0}$. Usually, in the young soils (Entisols or Inceptisols) PZNC is lower than its $\mathrm{pH}_{0}$ and higher than $\mathrm{pH}_{0}$ if the soils are highly weathered, such as Oxisols [41]. In addition, the model of Uehara and Gillman [11] and Yu [2] predict that in soils having constant negative charge, the PZNC value is lower than $\mathrm{pH}_{0}$ and vice versa. None of the charge variation curves of the samples indicated the PZNC in $\mathrm{pH}$ between ranges of 2.6 and 6, which was due to the excessive amount of negative charge compared with the positive charge in these ranges of $\mathrm{pH}$. Besides, the amount of estimated ZPNC in all the samples was lower than the $\mathrm{pH}_{0}$, confirming the presence of the permanent negative charge in these soils. 


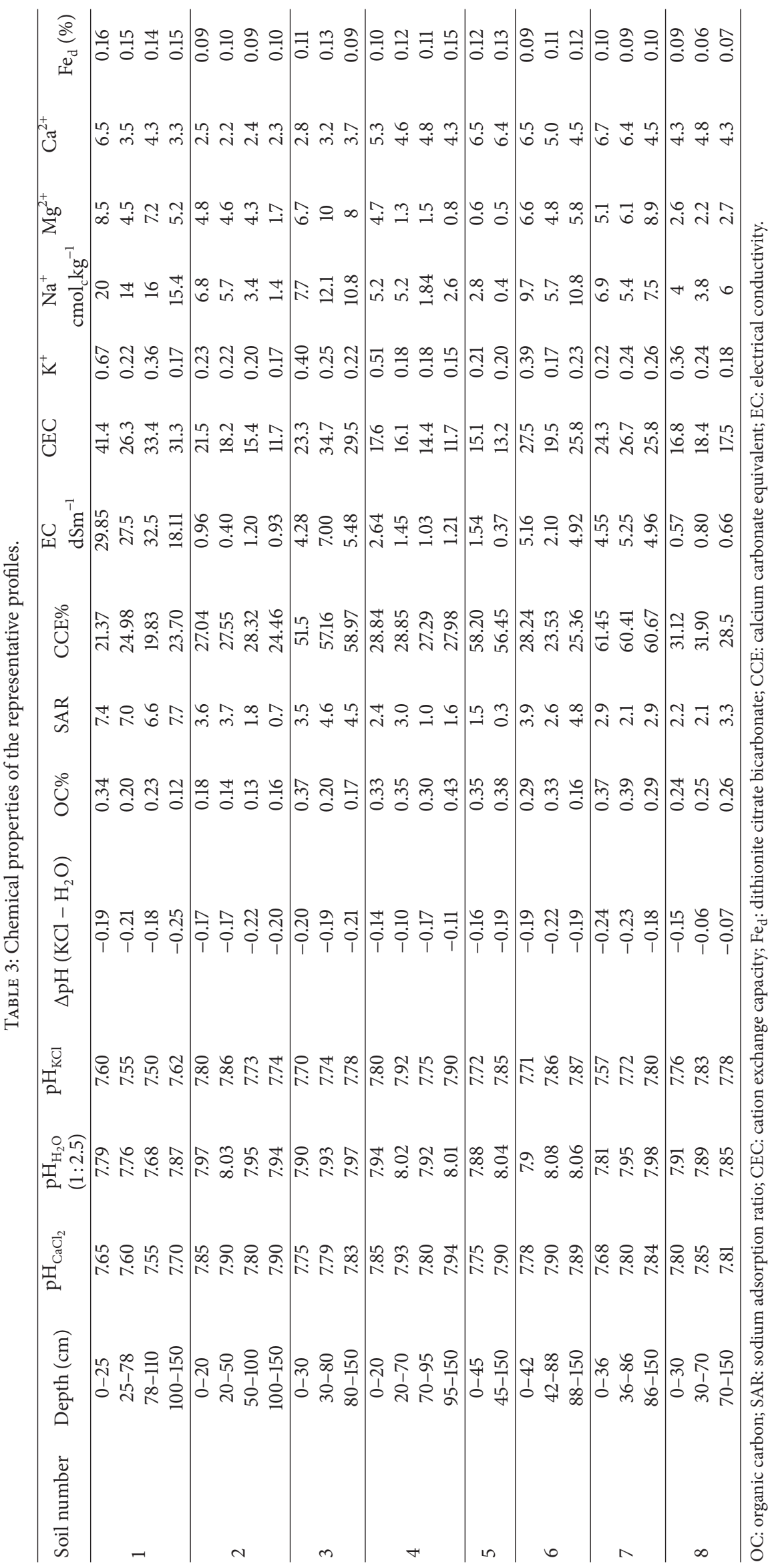




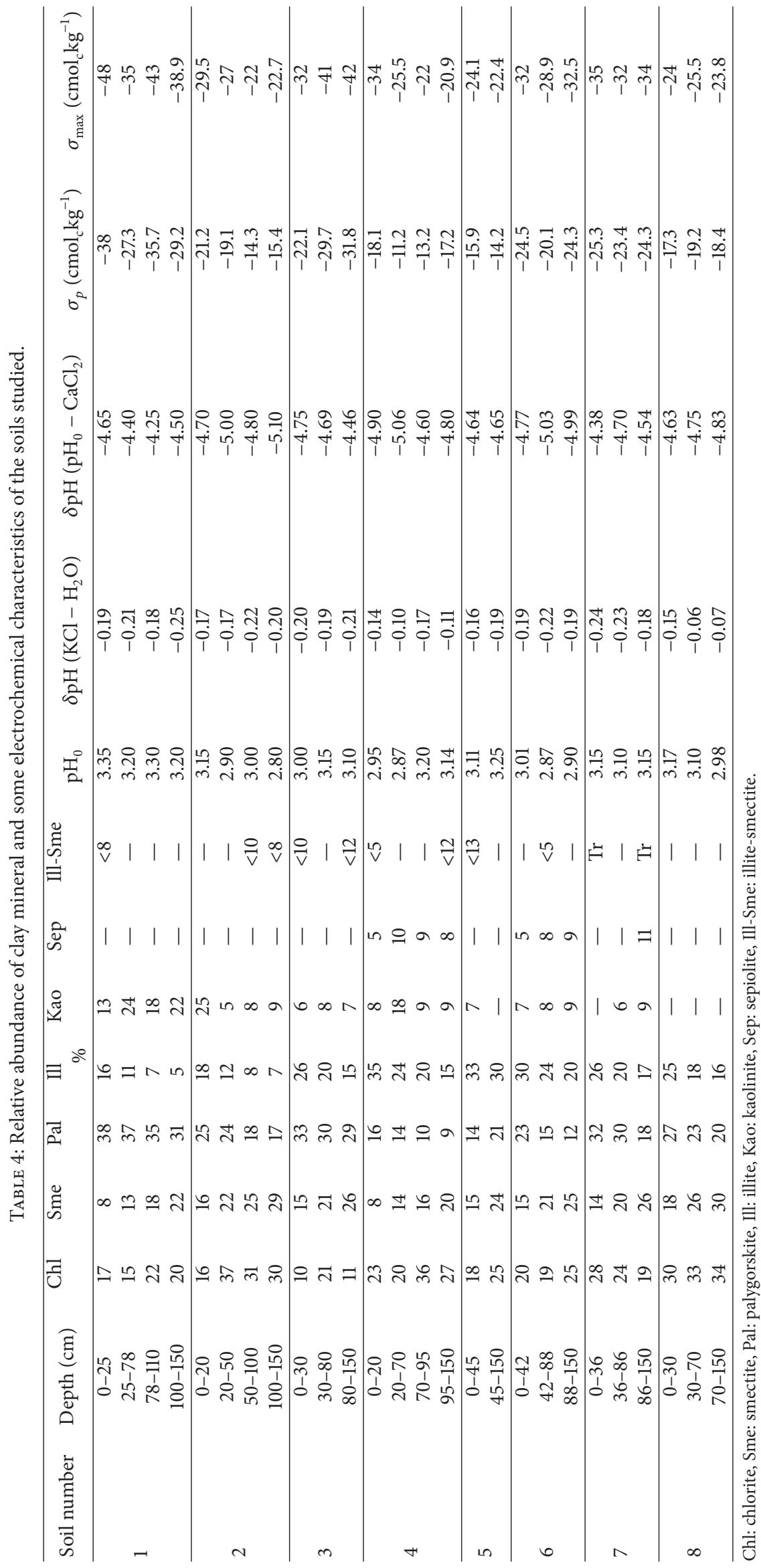


These data also agree with their mineralogical information (Table 4).

3.5.3. Permanent Negative Charge $\left(\sigma_{p}\right)$. The $\sigma_{p}$ has a positive significant correlation with $\mathrm{Fe}_{\mathrm{d}}\left(r=0.63^{* *}, P<0.01\right)$. Earlier, the effects of $\mathrm{Fe}_{\mathrm{d}}$ on the surface charge properties were discussed. Hamdan et al. [42] showed that charge characteristics were significantly correlated with soil organic matter, free iron oxides, and clay content. Sesquioxides have amphoteric properties; that is, their surface charge can bear either positive charge in an acid condition or negative charge in an alkaline condition [43].

The $\sigma_{p}$ has a positive significant correlation with clay content $\left(r=0.54^{* *}, P<0.01\right)$. The results agree well with those of Sharami et al. [6]. At high $\mathrm{pH}, \mathrm{OH}^{-}$ions interact with the edge of the clay particles, making them neutral or negatively charged [44].

The mineralogical compositions in these soils were mixed and each clay mineral plays an important role in the total permanent charge. Although all soils are a mixture of permanent and variable-charge components, whether one or the other dominants depends largely on its mineralogy [45]. For instance, palygorskite has a positive significant correlation with $\sigma_{p}\left(r=0.60^{* *}, P<0.01\right)$. Structurally, palygorskite includes alternation of blocks and tunnels that grow along the length of the fiber. Each structural block is composed of two discontinuous tetrahedral sheets of silica that a central octahedral sheet sandwiched between them. Because of the discontinuity of the silica sheets, silanol groups ( $\mathrm{Si}-\mathrm{OH})$ are present on the surface of the fiber.

The $\sigma_{p}$ has a positive significant correlation with OC ( $r=$ $\left.0.60^{* *}, P<0.01\right)$. Organic matter also acts as an important source of surface negative charge. Oades et al. [46] reported several relationships between surface charge characteristics and organic matter in an Oxisol under rainforest vegetation in Australia. Hydroxyl groups of organic matter can also contribute to negative charge [2]. Shamshuddin and Anda [47] showed that organic carbon in soils is responsible for lowering the $\mathrm{pH}_{0}$ because of the creation of negative surface charge and/or masking of positive surface charge.

The SAR, exchangeable $\mathrm{Na}$ and exchangeable $\mathrm{Mg}$ also have a positive significant correlation with $\sigma_{p}$ with $r$-values of $0.84^{* *}, 0.92^{* *}$, and $0.82^{* *}$, respectively. Through alteration of the crystal lattice structure of soil colloids, permanent charge develops when ions of lower valence substitute for ions of higher valence [48]. The mechanisms of the effect of electrolyte on surface charge of soils are rather complex. According to the theory of diffuse double layer, two mechanisms may exist. The surface of variable charge minerals is one kind of reversible constant potential surface. The charge density $\delta$ on this type of surface is proportional to the square root of ion concentration $C$ of the solution, that is, $\delta=$ $K(C)^{1 / 2}$, where $K$ is a constant [28].

The valence, ionic radius, and thickness of hydrated layer of cations and anions of various electrolytes are different. Morais et al. [49] showed that the nature and valence of the counterions also influenced the magnitude of the electric charges on the soil particles. For example, the quantities of negative surface charge and net surface charge in $\mathrm{MgCl}_{2}$, $\mathrm{MgSO}_{4}$, and $\mathrm{K}_{2} \mathrm{SO}_{4}$ solutions are lower than those in $\mathrm{KCl}$ solution.

Furthermore, the $\sigma_{p}$ has a positive significant correlation with CEC $\left(r=0.96^{* *}, P<0.01\right)$. This demonstrates that the CEC has the highest effect on the $\sigma_{p}$. Since organic matter is low in the soils, the CEC is affected by the expanding minerals (e.g., smectite) [50] and basic exchangeable cations (e.g., $\mathrm{Na}$ ). Sollins et al. [45] reported that most of the permanent charge in the soils is on the surfaces of layer-silicate clays, which compose most of the surface area of p-c soils. These clays include the 2:1 layer-silicates (illite, vermiculite, and smectite) and the $2: 2$ clays (chlorite). The $1: 1$ group of kaolin clays has a small amount of permanent charge on their surface.

The $\mathrm{pH}_{\mathrm{H}_{2} \mathrm{O}}$ has a positive significant correlation with the permanent negative charge $\left(\sigma_{p}\right)\left(r=0.72^{* *}, P<0.01\right)$. The $\mathrm{pH}_{\mathrm{KCl}}$ also has a positive significant correlation with the permanent negative charge $\left(\sigma_{p}\right)\left(r=0.55^{* *}, P<0.01\right)$. Rashad and Dultz [51] indicated that at low $\mathrm{pH}$ the surface charge of both clay soil samples (original clay and the organic matter removed clay soil) had low negative values, which is due to the protonation of variable charge with increasing $\mathrm{pH}$, where deprotonation of functional groups occurs, the surface charge becomes more negative. Shamshuddin et al. [52] reported that the negative charges on the soil surface were found to increase significantly with an increase in $\mathrm{pH}$. Thus, when the $\mathrm{pH}$ is raised, more $\mathrm{OH}^{-}$are adsorbed onto the surface or $\mathrm{H}^{+}$are released into the solution, causing an increase in negative charges.

3.5.4. Charge Variation with $\mathrm{pH}$. Charge (negative and positive) variations with $\mathrm{pH}\left(0.002 \mathrm{M} \mathrm{CaCl}_{2}\right)$ for different horizons of the soils are presented in Figure 2. The inverse relations between both negative and positive charge variation curves both in surface and between subsurface horizons (having small levels of variable charge components) were noticeable. The results showed that all of the samples showed large negative charge over the range of applied $\mathrm{pH}$. The highest level of negative charge was evident in profile 1 , which was probably due to high levels of clay content in its surface and subsurface horizons and the relation to $2: 1$ clay minerals. The charge properties did not show any clear trend with depth. Since the plain is part of an alluvial and colluvial fan, the deposition of materials from the alluvial and colluvial wash varies from time to time creating different textural layers. For instance, the level of negative charge in horizon Czl $\left(-27.3 \mathrm{cmol}_{\mathrm{c}} \mathrm{kg}^{-1}\right)$ of profile 1 (Calcic Haplosalids) was lower than that of horizon Cyz2 $\left(35.7 \mathrm{cmol}_{\mathrm{c}} \mathrm{kg}^{-1}\right)$. Hence, the soil electrochemical properties in profile 1 were different from the other studied pedons.

Profile 4 (horizon $\mathrm{C}_{1}$ ) has the lowest negative charge (11.2 $\mathrm{cmol}_{\mathrm{c}} \mathrm{kg}^{-1}$ ), which is probably due to low levels of clay content and the relatively low smectite in this layer. Profile 4 also shows the lowest levels of negative charge in both surface and subsurface horizons compared with the other profiles, due to its lower CEC, clay content, and smectite.

The negative charge of the soils in the present study is influenced by the $2: 1$ clay minerals where they are prevalent 

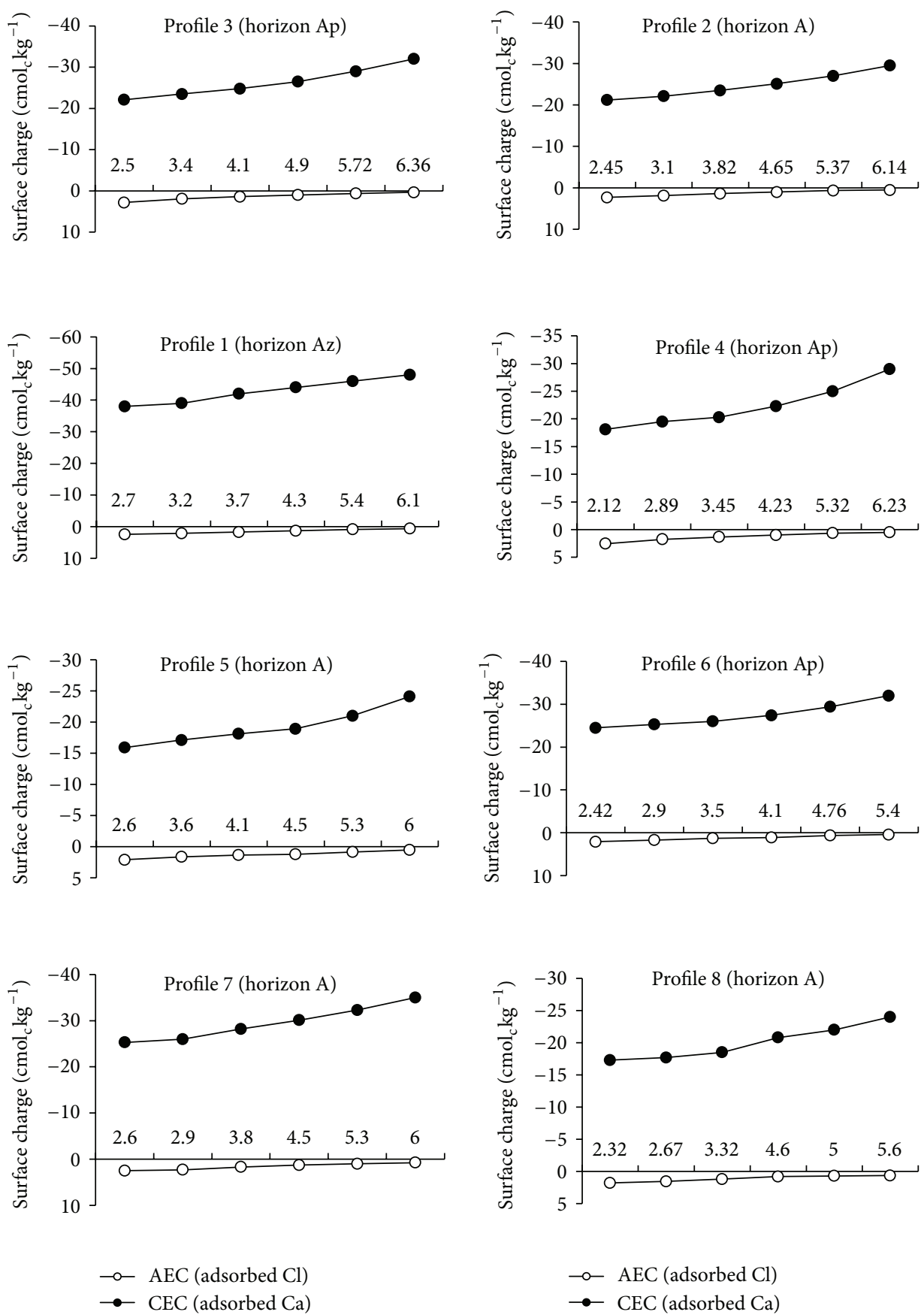

FIGURE 2: Charge variation with soil $\mathrm{pH}\left(0.002 \mathrm{M} \mathrm{CaCl}_{2}\right)$ for different horizons.

and organic matter accompanied by iron oxide is scarce (Tables 3 and 4). Consequently, $\mathrm{pH}$ variations could not have a great influence on the charge curve. Therefore, for soil $\mathrm{pH}\left(\mathrm{CaCl}_{2}\right)$ of 7.55 , the amount of negative charge in the subsurface horizon of profile 1 is more than the above horizon. Naidu et al. [53] studied the clay mineralogy and surface charge characteristics of four basaltic soils from Western Samoa. The level of trace to subordinate amounts of kaolin minerals was present in these soils. The surface charge$\mathrm{pH}$ curves followed a constant potential model, indicating the presence of substantial amounts of $\mathrm{pH}$-dependent charge.
In addition, they reported that negative charge was present at $\mathrm{pH}$ values as low as 3.0 and small quantities of positive charge were detected at $\mathrm{pH}$ values as high as 9.0. Values for PZC ranged from 2.2 to 3.9 and these were generally greater than the $\mathrm{pH}_{0}$ determined by $\delta \mathrm{pH}$ method in their study. The permanent negative charge of the soils is high because the majority of parent materials are limestone. The results agreed well with those obtained by Sharami et al. [6].

Generally, for all the soils examined, the ranges of charge variation with $\mathrm{pH}$ in the surface horizons were more noticeable than in the subsurface horizons. Most of these 
variations were observed in the $\mathrm{pH}$ ranging from 3.5 to 5.0, where the curves had a descending trend.

The values of anion exchange capacity (AEC) in most of the studied soils showed small levels, which were due to a shortage of materials having variable charge. However, organic matter and kaolinite are present in these soils, but these materials do not enhance the AEC level with respect to their intrinsic characteristics and soil $\mathrm{pH}$. Another reason for this observation (small level of AEC) was negative adsorption (repulsion) of anions from surfaces with variable charge. Adsorption of anions is one of the important characteristics of variable-charge soils. Owing to the properties of variablecharge soils in chemical and mineralogical compositions, adsorption of anions by these soils would have been more significant compared with adsorption by constant-charge soils [54]. Soils having variable charge, occupying large areas in tropical and subtropical regions, are characterized by carrying variable amounts of both negative and positive charges and therefore can adsorb both cations and anions [55]. Hence, the soils of the present study, due to a shortage of materials having variable charge, which is a common property of soils from humid regions, had small capacity levels for anion adsorption.

\section{Conclusion}

The soils of the studied area are young, dominantly of Aridisols and Entisols. Their mineralogy is dominated by the $2: 1$ silicate layer clay minerals. Consequently, the $\mathrm{pH}_{0}$ and the PZNC values in the arid soils are low in comparison with tropical soils. The $\mathrm{pH}_{0}$ values of all samples are less than $\mathrm{pH}$ under the field condition because of the high $\mathrm{pH}$ and the presence of high amount of $2: 1$ silicate clay minerals. Charge variation curves in the soils did not give $\mathrm{PZNC}$ values within $\mathrm{pH}$ range of 2.6 to 6 . The $\mathrm{PZNC}$ values are less than $\mathrm{pH}_{0}$ in all samples. However, permanent negative charge $\left(\sigma_{p}\right)$ is high in the arid soils because of presence of clay minerals $(2: 1$ and $1: 1$ types). Hence, the $\sigma_{p}$ has a significant positive correlation with $\mathrm{pH}, \mathrm{CEC}, \mathrm{OC}, \mathrm{SAR}, \mathrm{Na}, \mathrm{Mg}$, clay, and palygorskite. The charge variation curves showed that the AEC values are small with values of $<2.83 \mathrm{cmol}_{\mathrm{c}} \mathrm{kg}^{-1}$.

After this study we can recommend the application of fertilizers based on the amount of negative charges in the soils studied.

\section{Acknowledgments}

The authors are thankful to Universiti Putra Malaysia for technical and financial support. They also thank members of the Department of Land Management for providing laboratory facilities to carry out this study.

\section{References}

[1] X. N. Zhang and A. Z. Zhao, "Surface charge," in Chemistry of Variable Charge Soils, T. R. Yu, Ed., pp. 17-63, Oxford University Press, New York, NY, USA, 1997.
[2] T. R. Yu, Chemistry of Variable Charge Soils, Oxford University Press, New York, NY, USA, 1997.

[3] J. Chorover, M. K. Amistadi, and O. A. Chadwick, "Surface charge evolution of mineral-organic complexes during pedogenesis in Hawaiian basalt," Geochimica et Cosmochimica Acta, vol. 68 , no. 23, pp. 4859-4876, 2004.

[4] M. Barale, C. Mansour, F. Carrette et al., "Characterization of the surface charge of oxide particles of PWR primary water circuits from 5 to $320^{\circ} \mathrm{C}$," Journal of Nuclear Materials, vol. 381, no. 3, pp. 302-308, 2008.

[5] G. Uehara and G. P. Gillman, The Mineralogy, Chemistry and Physics of Tropical Soils with Variable Charge Clays, West View Press, Boulder, Colo, USA, 1981.

[6] S. M. Sharami, A. Forghani, A. Akbarzadeh, and H. Ramezanpour, "Mineralogical characteristics and related surface charge fluctuations of some selected soils of temperate regions of northern Iran," Clay Minerals, vol. 45, no. 3, pp. 327-348, 2010.

[7] M. Anda, J. Shamshuddin, C. I. Fauziah, and S. R. S. Omar, "Mineralogy and factors controlling charge development of three Oxisols developed from different parent materials," Geoderma, vol. 143, no. 1-2, pp. 153-167, 2008.

[8] T. Hou, R. Xu, D. Tiwari, and A. Zhao, "Interaction between electrical double layers of soil colloids and Fe/Al oxides in suspensions," Journal of Colloid and Interface Science, vol. 310, no. 2, pp. 670-674, 2007.

[9] C. Taubaso, M. Dos Santos Afonso, and R. M. Torres Sánchez, "Modelling soil surface charge density using mineral composition," Geoderma, vol. 121, no. 1-2, pp. 123-133, 2004.

[10] A. Gonzales-Batista, J. M. Hernandez-Moreno, E. FernandezCaldas, and A. J. Herbillon, "Influence of silica content on the surface charge characteristics of allophanic clays," Clays \& Clay Minerals, vol. 30, no. 2, pp. 103-110, 1982.

[11] G. Uehara and G. P. Gillman, "Charge characteristics of soils with variable and permanent charge minerals-I. Theory," Soil Science Society of America Journal, vol. 44, pp. 404-409, 1980.

[12] N. C. Brady and R. R. Weil, The Nature and Properties of Soils, Prentice Hall, Upper Sadller River, NJ, USA, 13th edition, 2002.

[13] G. Bellini, M. E. Sumner, D. E. Radcliffe, and N. P. Qafoku, "Anion transport through columns of highly weathered acid soil: adsorption and retardation," Soil Science Society of America Journal, vol. 60, no. 1, pp. 132-137, 1996.

[14] D. J. Burdon, "Hydrogeological conditions in the Middle East," Quarterly Journal of Engineering Geology, vol. 15, no. 2, pp. 7182, 1982.

[15] M. H. Banaei, "Soil moisture and temperature region map of Iran," Soil and Water Research Institute, Ministry of Agriculture, Tehran, Iran, 1998.

[16] A. H. Moghimi, "Semi-detailed soil survey and classification in Ashkara plain, Iran,” Soil and Water research institute, Ministry of Agriculture, Tehran, Iran, 2002.

[17] Soil Survey Staff, "Soil survey laboratory methods manual," Soil survey investigation report No. 42, version 4, Washington, DC, USA, 2004.

[18] Soil Survey Staff, "Keys to Soil Taxonomy," U.S. Department of Agriculture, NRCS, 2010.

[19] G. W. Gee and J. W. Bauder, "Particle size analysis," in Methods of Soil Analysis, A. Klute, Ed., vol. 9 of Agronomy Monograph 9, ASA and SSSA, Madison, Wis, USA, 2nd edition, 1986.

[20] A. Walkley and C. A. Black, "A critical examination of rapid method for determining organic carbon in soils: effect of variations in digestion conditions and of inorganic soil constituents," Soil Science, vol. 63, pp. 251-263, 1947. 
[21] O. P. Mehra and M. L. Jackson, "Iron oxide removal from soils and clays by a dithionitecitrate system buffered with sodium bicarbonate," Clay Minerals, vol. 7, pp. 317-327, 1980.

[22] M. K. Conyers and B. G. Davey, "Observations on some routine methods for soil pH determination," Soil Science, vol. 145, no. 1, pp. 29-36, 1988.

[23] L. P. Van Reeuwijk, "Procedures for soil analysis," in Proceedings of the International Soil Conference, Information Centre, Netherlands, 2002.

[24] G. R. Blake and K. H. Hartge, "Bulk density", in Methods of Soil Analysis-Part 1. Physical and Mineralogical Methods, A. Klute, Ed., Agronomy Monograph 9, ASA and SSSA, Madison, Wis, USA, 2nd edition, 1986.

[25] Salinity Laboratory Staff, Diagnosis and Improvement of Saline and Alkali Soils, USDA Handbook No. 60, Washington, DC, USA, 1954.

[26] L. E. Allison and C. D. Moodi, "Carbonate," in Methods of Soil Analysis, C. A. Black, Ed., vol. 9 of Agronomy, pp. 1379-1396, 1965.

[27] G. P. Gillman and M. E. Sumner, "Surface charge characterization, and soil solution composition of four soils from the Southern Piedmont in Georgia," Soil Science Society of America Journal, vol. 51, no. 3, pp. 589-594, 1987.

[28] H. Van Olphen, An Introduction to Clay Colloid Chemistry, Interscience, New York, NY, USA, 2nd edition, 1977.

[29] G. P. Gillman and G. Uehara, "Charge characteristics of soils with variable and permanent charge minerals-II. Experimental," Soil Science Society of America Journal, vol. 44, pp. 252-255, 1980.

[30] J. A. Kittrick and E. W. Hope, "A procedure for the particle size separation of soils for X-ray diffraction analysis," Soil Science, vol. 96, pp. 312-325, 1963.

[31] M. L. Jackson, Soil Chemical Analysis. Advanced Course, University of Wisconsin, College of Agriculture, Department of soils, Madison, Wis, USA, 1975.

[32] A. D. Karathanasis and B. F. Hajek, "Revised methods for rapid quantitative determination of minerals in soil clays," Soil Science Society of America Journal, vol. 46, no. 2, pp. 419-425, 1982.

[33] F. Khormali and A. Abtahi, "Origin and distribution of clay minerals in calcareous arid and semi-arid soils of Fars Province, southern Iran," Clay Minerals, vol. 38, no. 4, pp. 511-528, 2003.

[34] S. A. Khresat and E. A. Qudah, "Formation and properties of aridic soils of Azraq Basin in northeastern Jordan," Journal of Arid Environments, vol. 64, no. 1, pp. 116-136, 2006.

[35] I. Navai, "Explanatory Text of the Hajiabad Quadrangle map 1/250000," Geological Survey of Iran, 1976.

[36] H. R. Owliaie, A. Abtahi, and R. J. Heck, "Pedogenesis and clay mineralogical investigation of soils formed on gypsiferous and calcareous materials, on a transect, southwestern Iran," Geoderma, vol. 134, no. 1-2, pp. 62-81, 2006.

[37] M. Emadi, M. Baghernejad, H. Memarian, M. Saffari, and H. Fathi, "Genesis and clay mineralogical investigation of highly calcareous soils in semi-arid regions of Southern Iran," Journal of Applied Sciences, vol. 8, no. 2, pp. 288-294, 2008.

[38] H. Khademi and J. M. Arocena, "Kaolinite formation from palygorskite and sepiolite in rhizosphere soils," Clays and Clay Minerals, vol. 56, no. 4, pp. 429-436, 2008.

[39] C. A. Coles and R. N. Yong, "Humic acid preparation, properties and interactions with metals lead and cadmium," Engineering Geology, vol. 85, no. 1-2, pp. 26-32, 2006.
[40] S.-Z. Li and R.-K. Xu, "Electrical double layers' interaction between oppositely charged particles as related to surface charge density and ionic strength," Colloids and Surfaces A, vol. 326, no. 3, pp. 157-161, 2008.

[41] E. Tessens and J. Shamshuddin, Quantitative Relationships between Mineralogy and Properties of Tropical Soils, UPM Press, Serdang, Malaysia, 1983.

[42] J. Hamdan, B. Ruhana, and C. P. Burnham, "Surface charge distribution of Three deep regoliths from Peninsular Malaysia," Journal of Sustainable Agriculture, vol. 18, no. 1, pp. 5-22, 2001.

[43] N. P. Qafoku, E. Van Ranst, A. Noble, and A. Baert, "Variable charge soils: their mineralogy, chemistry and management," Advances in Agronomy, vol. 84, pp. 159-215, 2004.

[44] G. Sposito, The Chemistry of Soils, Oxford University Press, New York, NY, USA, 1989.

[45] P. Sollins, G. P. Robertson, and G. Uehara, "Nutrient mobility in variable- and permanent-charge soils," Biogeochemistry, vol. 6, no. 3, pp. 181-199, 1988.

[46] J. M. Oades, G. P. Gillman, and G. Uehara, "Interactions of soil organic and variable-charge clays," in Dynamics of Soil Organic Matter in Tropical Ecosystems, D. C. Coleman, J. M. Oades, and G. Uehara, Eds., pp. 69-95, University of Hawaii Press, Honolulu, Hawaii, USA, 1989.

[47] J. Shamshuddin and M. Anda, "Charge properties of soils in Malaysia dominated by kaolinite, gibbsite, goethite and hematite," Bulletin of the Geological Society of Malaysia, vol. 54, pp. 27-31, 2008.

[48] J. B. Yavitt and S. J. Wright, "Charge characteristics of soil in a lowland tropical moist forest in Panama in response to dryseason irrigation," Australian Journal of Soil Research, vol. 40, no. 2, pp. 269-281, 2002.

[49] F. I. Morais, A. L. Paga, and L. J. Lund, "The effect of pH, salt concentration, and nature of electrolytes on the charge characteristics of Brazilian tropical soils," Soil Science Society of America Journal, vol. 40, pp. 521-527, 1976.

[50] C. A. Igwe, F. O. R. Akamigbo, and J. S. C. Mbagwu, "Chemical and mineralogical properties of soils in southeastern Nigeria in relation to aggregate stability," Geoderma, vol. 92, no. 1-2, pp. 111-123, 1999.

[51] M. Rashad and S. Dultz, "Decisive factors of clay dispersion in alluvial soils of the Nile River Delta-a study on surface charge properties," American-Eurasian Journal of Agricultural \& Environmental Sciences, vol. 2, pp. 213-219, 2007.

[52] J. Shamshuddin, S. Paramananthan, and N. Mokhtar, "Mineralogy and surface charge properties of two acid sulfate soils from Peninsular Malaysia," Pertanika, vol. 9, pp. 167-176, 1986.

[53] R. Naidu, R. J. Morrison, L. Janik, and M. Asghar, "Clay mineralogy and surface charge characteristics of basaltic soils from Western Samoa," Clay Minerals, vol. 32, no. 4, pp. 545-556, 1997.

[54] J. Li, R. Xu, S. Xiao, and G. Ji, "Effect of low-molecular-weight organic anions on exchangeable aluminum capacity of variable charge soils," Journal of Colloid and Interface Science, vol. 284, no. 2, pp. 393-399, 2005.

[55] R. Xu, A. Zhao, and G. Ji, "Effect of low-molecular-weight organic anions on surface charge of variable charge soils," Journal of Colloid and Interface Science, vol. 264, no. 2, pp. 322326, 2003. 

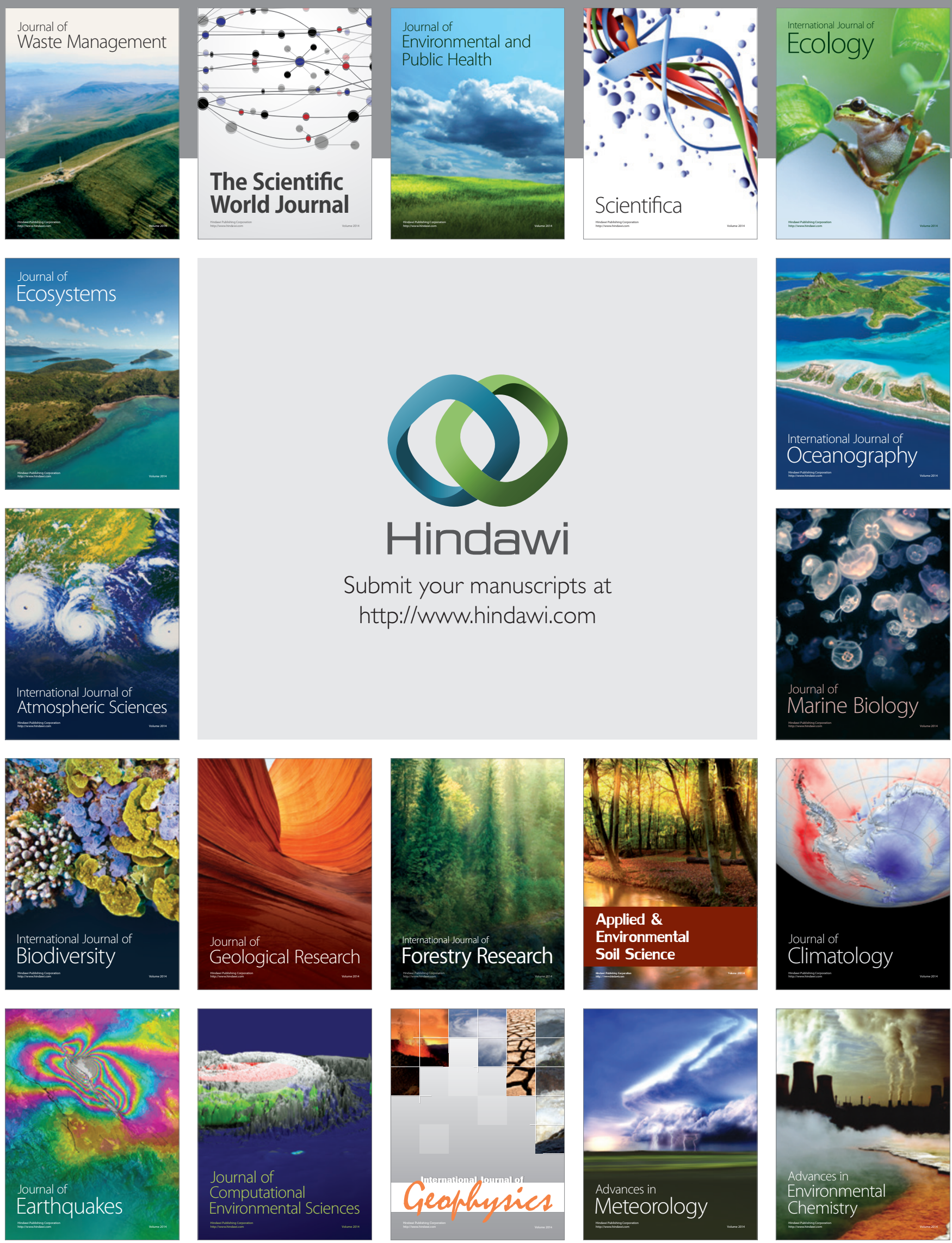